
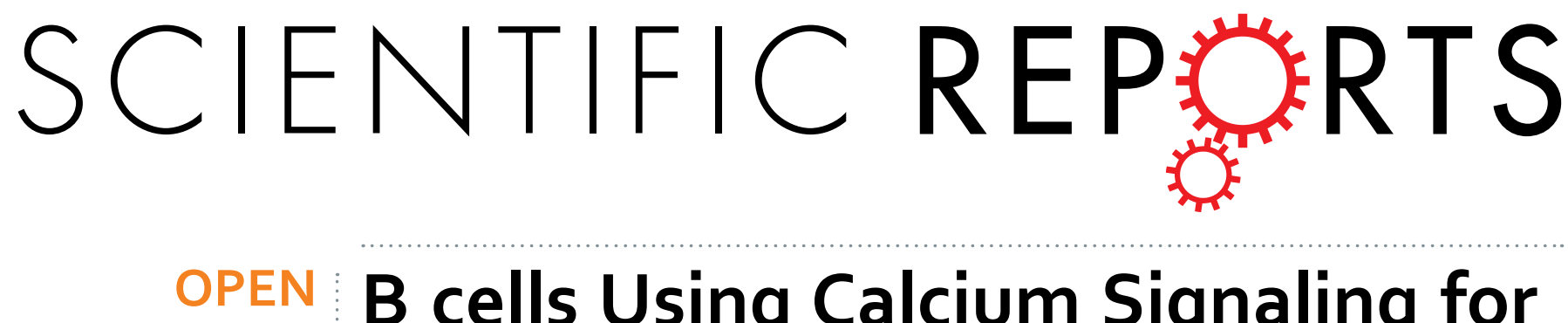

\title{
B cells Using Calcium Signaling for Specific and Rapid Detection of Escherichia coli $\mathrm{O}_{157}: \mathrm{H}_{7}$
}

Received: 26 September 2014

Accepted: 20 April 2015

Published: 02 June 2015

\author{
Ling Wang ${ }^{1,2}$, Ronghui Wang ${ }^{2}$, Byung-Whi Kong ${ }^{3}$, Sha $\mathrm{Jin}^{4}$, Kaiming Ye ${ }^{4}$, Weihuan Fang ${ }^{5}$ \& \\ Yanbin $\mathrm{Li}^{1,2}$
}

A rapid and sensitive detection technology is highly desirable for specific detection of $E$. coli $\mathrm{O}_{157}: \mathrm{H}_{7}$, one of the leading bacterial pathogens causing foodborne illness. In this study, we reported the rapid detection of $E$. coli $\mathrm{O}_{157}: \mathrm{H}_{7}$ by using calcium signaling of the $\mathrm{B}$ cell upon cellular membrane anchors anti-E. coli $\mathrm{O}_{157}: \mathrm{H}_{7} \mathrm{IgM}$. The binding of $E$. coli $\mathrm{O}_{157}: \mathrm{H}_{7}$ to the $\operatorname{lgM}$ on $\mathrm{B}$ cell surface activates the $\mathrm{B}$ cell receptor (BCR)-induced $\mathrm{Ca}^{2+}$ signaling pathway and results in the release of $\mathrm{Ca}^{2+}$ within seconds. The elevated intracellular $\mathrm{Ca}^{2+}$ triggers Fura-2, a fluorescent $\mathrm{Ca}^{2+}$ indicator, for reporting the presence of pathogens. The Fura- 2 is transferred to $B$ cells before detection. The study demonstrated that the developed $B$ cell based biosensor was able to specifically detect $E$. coli $\mathrm{O}_{157}: \mathrm{H}_{7}$ at the low concentration within $10 \mathrm{~min}$ in pure culture samples. Finally, the B cell based biosensor was used for the detection of $E$. coli $\mathrm{O}_{157}: \mathrm{H}_{7}$ in ground beef samples. With its short detection time and high sensitivity at the low concentration of the target bacteria, this $B$ cell biosensor shows promise in future application of the high throughput and rapid food detection, biosafety and environmental monitoring.

There are estimated 48 million cases of foodborne illness resulting in 3,000 deaths, and an estimated cost of 78 billion dollars per year ${ }^{1-3}$. It has been continuously a major public health and economic burden for the United States and worldwide 4 . In particular, foodborne bacteria such as Campylobacter jejuni, Listeria monocytogenes, Salmonella enterica, E. coli O157:H7 and other shiga-toxin producing E. coli strains (non-O157 STEC), and Vibrio spp. are leading causes of foodborne diseases 5 . E. coli O157:H7 has been identified as a major etiologic agent, which is one cause of foodborne illness and has been found to contaminate spinach, lettuce, cider, ground beef, and cantaloupe, which is also one of the top six pathogens contributing to domestically acquired foodborne illnesses resulting in hospitalization $(38 \%)^{6}$. Therefore, rapid detection of microbial pathogens in food is the solution to the prevention and recognition of problems related to health and safety.

Cell-based biosensors (CBBs) present promises of equally reliable results in much shorter times ${ }^{7}$. The sensing elements of CBBs could be vegetative cells of bacteria ${ }^{8,9}$, eukaryotic ${ }^{10}$ or mammalian cells ${ }^{11-15}$. The ability of cells to recognize and respond to stimuli has made them attractive for incorporating them into biosensors. Besides neurons, cardiac cells, adenocarcinoma cell line, more and more lymphocytes have been studied in CBBs, such as B cells, mast cells, T cells, etc ${ }^{16-24}$. Among them, B cells showed the superiority of pathogen detection in speed and sensitivity due to their capability of antigen internalization through BCR (B Cell Receptors) for processing and presentation to T cells ${ }^{25}$. Murine hybridoma B cells (Ped-2E9) have been used for rapid detection of pathogenic Listeria, the toxin listeriolysin O and the enterotoxin from Bacillus species ${ }^{13,25,26}$. Rider et al. ${ }^{11}$ used the genetically engineered B lymphocyte

${ }^{1}$ College of Biosystems Engineering and Food Science, Zhejiang University, Hangzhou 310058, China. ${ }^{2}$ Department of Biological and Agricultural Engineering, University of Arkansas, Fayetteville, AR 72701, USA. ${ }^{3}$ Department of Poultry Science, University of Arkansas, Fayetteville, AR 72701, USA. 4Department of Biomedical Engineering, Binghamton University-SUNY, Binghamton, NY 13902, USA. 5College of Animal Sciences, Zhejiang University, Hangzhou 310058, China. Correspondence and requests for materials should be addressed to Y.L. (email: yanbinli@zju.edu.cn) 
a

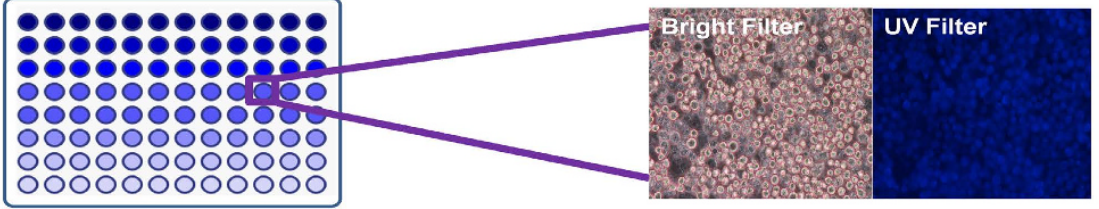

b

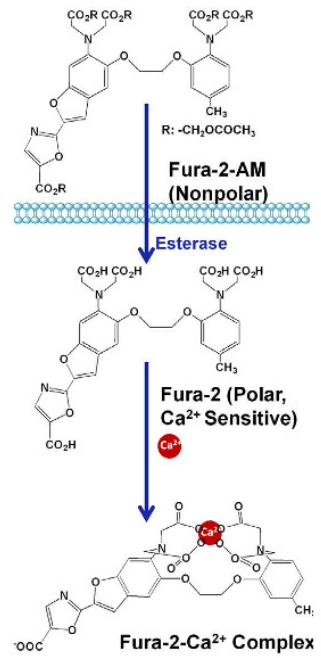

C

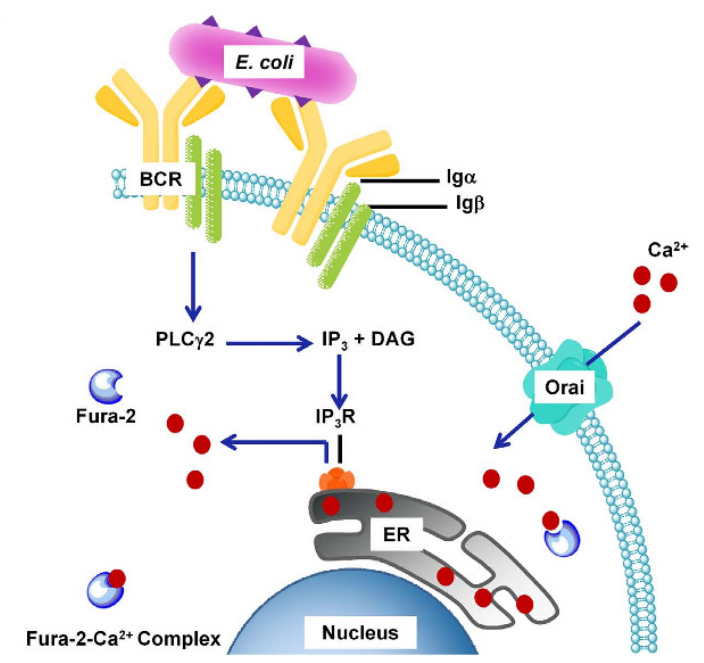

Figure 1. Principles of the B cell biosensor. (a). The response signal of the B cell biosensor was measured by a microplate reader. (b). Structural changes of Fura- 2 by esterase activity and $\mathrm{Ca}^{2+}$ binding. Fura- 2 $\mathrm{AM}$ ester is $\mathrm{Ca}^{2+}$ insensitive and nonpolar. Once inside the cell, esterase enzymes sequentially cleave the AM groups to leave Fura-2-free acid $\left(\mathrm{Ca}^{2+}\right.$ sensitive, polar) trapped inside the cell, where it is able to bind $\mathrm{Ca}^{2+}$. (c). The cellular working principle of the $\mathrm{B}$ cell biosensor. When the target pathogen is attached to its specific receptors on the B cell surface, the cross-linking of B cell receptors (BCRs) will produce a signal, and the signaling pathways will be activated, resulting in the release of $\mathrm{Ca}^{2+}$ within seconds. Fura- 2 exhibits a calcium dependent excitation spectral shift to report the 340/380 ratio and indicate the presence of the target pathogen.

cells for a rapid identification of pathogens and could detect E. coli O157:H7 as little as 500 CFU/g in $5 \mathrm{~min}$ or less ${ }^{11}$. B cells are known as the fastest pathogen identifiers (intrinsic response in $\left.<1 \mathrm{~s}\right)^{27,28}$, since calcium ion plays a pivotal role in the regulation of various cellular processes in eukaryotic cells. One of the primary consequences of this identification in a B cell is that a molecule binding to BCR induces a change of $\mathrm{Ca}^{2+}$ flux, which is a critical event in the response of a $\mathrm{B}$ cell to antigen stimulation ${ }^{29}$.

A series of fluorescent calcium indicator dyes have been developed for measurement of free intracellular calcium in eukaryotic cells and prokaryote. Fura- 2 has been known as an indicator dye for measuring the concentration of free calcium $\left(\left[\mathrm{Ca}^{2+}\right]_{\mathrm{i}}\right)$ within living cells ${ }^{30,31}$. The ratio of fluorescence emission at the two excitation wave lengths $(340: 380)$ is considered a reliable indicator of $\left[\mathrm{Ca}^{2+}\right]_{i}^{32,33}$. It has been widely used but not limited in immunology, cytology and neurology for interrogating ion channels ${ }^{34-36}$. and calcium signaling ${ }^{37-39}$. However, to the best of our knowledge, there is no report on utilization of Fura-2 in B cells for the bacterial pathogen detection in the food sample.

In this study, we combined the properties of B cells and Fura-2 to develop a B cell biosensor with a low detection limit of E. coli $\mathrm{O} 157: \mathrm{H} 7$ and short detection time. The innovative approach in this study is the use of a Ca ${ }^{2+}$-indicator, Fura- 2 for detecting BCR-induced $\mathrm{Ca}^{2+}$ change due to an interaction between $\mathrm{B}$ cells and pathogens. The reaction mechanisms underlying intracellular calcium measurement using an $\mathrm{Ca}^{2+}$-indicator Fura-2 are discussed elsewhere ${ }^{31}$. It has been long known that the excitation spectrum of Fura-2 shifts rightward upon the binding of $\mathrm{Ca}^{2+}$. The excitation wavelength of Fura-2 shifts from $340 \mathrm{~nm}$ in the presence of $\mathrm{Ca}^{2+}$ to $380 \mathrm{~nm}$ in the absence of $\mathrm{Ca}^{2+}$. It was found that a fluorescence ratio at $340 / 380$ is correlated to a concentration of free intracellular $\mathrm{Ca}^{2+30}$. This technology has a great potential to provide a practical alternative for detection of E. coli $\mathrm{O} 157: \mathrm{H} 7$ and other pathogens.

\section{Results}

Principles of the B cell biosensor. Combining advantages of the sensitivity of Fura- 2 to $\mathrm{Ca}^{2+}$ and the rapidness of response of $\mathrm{B}$ cell to antigens, a $\mathrm{Ca}^{2+}$-indicator based $\mathrm{B}$ cell biosensor was designed for E. coli O157:H7 detection. As shown in Fig. 1a, Fura-2 loaded B cells were placed in 96-wells, and a fluorescence ratio (340:380) was measured after the addition of analytes. Fura-2 pentaacetoxymethyl (AM) 
ester was used in our experiments because this form of dye is $\mathrm{Ca}^{2+}$ insensitive and nonpolar. Once inside the cell, esterase enzymes sequentially cleave the AM groups to leave Fura-2-free acid $\left(\mathrm{Ca}^{2+}\right.$ sensitive, polar) trapped inside the cell and are ready for $\mathrm{Ca}^{2+}$ binding (Fig. 1b).

The specific B lymphocyte plays a major role in the recognition and capture of E. coli O157: H7. The BCR-induced $\mathrm{Ca}^{2+}$ flux occurs in seconds, and then B cells will exhibit increased BCR-evoked $\mathrm{Ca}^{2+}$ influx $^{29}$. As shown in Fig. 1c, the B lymphocyte immune response is initiated by the binding of an antigen to the $\mathrm{BCR}^{25}$. The $\mathrm{BCR}$ is a multisubunit protein complex composed of a membrane form of immunoglobulin (Ig) that is noncovalently associated with heterodimers of $\operatorname{Ig} \alpha$ and $\operatorname{Ig} \beta$. Crosslinking the BCR by the binding of bivalent or multivalent antigen leads to both transmembrane signaling and antigen internalization for presentation ${ }^{40}$. BCR-induced tyrosine phosphorylation of PLC- $\gamma 2$ is responsible for an increase in its activity, allowing the conversion of phosphatidylinositol 4,5-bisphosphate $\left(\mathrm{PIP}_{2}\right)$ to the second messengers inositol 1,4,5-trisphosphate $\left(\mathrm{IP}_{3}\right)$ and diacylglycerol (DAG). $\mathrm{IP}_{3}$ binds $\mathrm{IP}_{3}$ receptor $\left(\mathrm{IP}_{3} \mathrm{R}\right)$, which is localized primarily on the endoplasmic reticulum (ER) and stimulates the release of calcium from intracellular stores ${ }^{41}$. When ER Ca ${ }^{2+}$ depletion occurs, Orai, a plasma membrane protein and a pore subunit of the calcium-release activated channel (CRAC), triggers CRAC activation. Thus, localized $\mathrm{Ca}^{2+}$ influx is activated following $\mathrm{Ca}^{2+}$ depletion of $\mathrm{ER} \mathrm{Ca}^{2+}$ stores ${ }^{29,42,43}$. $\mathrm{IP}_{3}$ mediates a transient calcium release from intracellular stores, which leads to a sustained influx of calcium through $\mathrm{Ca}^{2+}$ channels in the plasma membrane, a process termed store-operated calcium entry ${ }^{44-46}$.

Optimization of the B cell biosensor. The experimental conditions such as B cell concentration, measurement time and existence of $\mathrm{Ca}^{2+}$ were interrogated to optimize the sensor. MARC 29F8 with membrane has monoclonal antibodies (MAbs) specific to the LPS of E. coli O157:H7 ${ }^{47}$. Upon arriving, the B cells were tested for the presence of antibodies through ELISA (Enzyme-linked immunosorbent assay). Whole cell ELISA analysis procedure is given in the Supplementary Information. ELISA results (Supplementary Fig. S1) confirmed the activity of antibodies on the membrane of selected B cells and the antibodies still have activity even after 12 passages of B cells. In this study, the early-passage numbers (passage numbers between 5 and 12) of B cells were used for B cell biosensor development. The binding of E. coli O157:H7 to the B cells was further confirmed through scanning electron microscopy (SEM). Representative SEM micrographic images are shown in Fig. $2 b$.

Fura-2 ratios $(F R)$ versus time were monitored using a microplate reader within 1 hour. After $10^{3} \mathrm{CFU} /$ $\mathrm{mL}$ of $E$. coli O157:H7 was added, the time point started as 0 min. As shown in Fig. 2c, a clearly increase in FR value was observed for E. coli O157:H7, when compared to the control (HBSS without target bacteria), which confirmed the sensing principle. In order to check the validation, further experiments were conducted to obtain the ratio of $\mathrm{Ca}^{2+}$-free $\left(\mathrm{Ca}_{\min }\right)$ and $\mathrm{Ca}^{2+}$-bound $\left(\mathrm{Ca}_{\max }\right)$ conditions. Results showed that the ratios of $F R$ and Control were between the ratios of $C a_{\text {min }}$ and $C a_{\text {max }}$, indicating that the obtained result was valid.

The gradual increase of Fura-2 ratio was observed in both FR and Control (Fig. 2c) during the detection time from 0 to $60 \mathrm{~min}$. This might be due to the leaking out of Fura- 2 from the cells, which should be subtracted before the calibration is performed ${ }^{32}$.

To investigate the variation of the biosensor whether there was the presence of $\mathrm{Ca}^{2+}$ in the solution, intracellular $\mathrm{Ca}^{2+}$ levels were measured with and without $\mathrm{Ca}^{2+}$ in the solution using different concentrations of B cells with adding different concentrations of $E$. coli $\mathrm{O} 157: \mathrm{H} 7\left(10^{1}-10^{9} \mathrm{CFU} / \mathrm{mL}\right)$. Paired $t$-test was conducted, as shown in Fig. 2d. In group NF (no Fura-2), B cells were not loaded with Fura-2, which was set as a blank control. The ratio obtained in NF6 (no Fura-2, $10^{6}$ cells $/ \mathrm{mL}$ ) was significantly higher than that obtained in NF5 (no Fura-2, $10^{5}$ cells/mL) $(p<0.0001)$. In group NC (no $\left.\mathrm{Ca}^{2+}\right)$, B cells were loaded with Fura-2 in the $\mathrm{Ca}^{2+}$ and $\mathrm{Mg}^{2+}$-free solution. There was no significant difference $(p>0.05)$ between NF5 (no Fura-2, $10^{5}$ cells/mL) and NF6. In group C (with $\mathrm{Ca}^{2+}$ ), B cells were loaded with Fura-2 in the $\mathrm{Ca}^{2+}$ and $\mathrm{Mg}^{2+}$ solution. The ratio obtained in $\mathrm{C} 6$ (with $\mathrm{Ca}^{2+}, 10^{6}$ cells $/ \mathrm{mL}$ ) was much higher than that obtained in $\mathrm{C} 5$ (with $\mathrm{Ca}^{2+}, 10^{5}$ cells $\left./ \mathrm{mL}\right)(p=0.0025)$. Since higher Fura-2 ratios were observed when the $10^{6}$ cells $/ \mathrm{mL}$ of B cells was tested in different groups, $10^{6}$ cells $/ \mathrm{mL}$ of B cells were used to carry out the comparison among the groups. The Fura-2 ratios obtained from NF6 were much lower than that obtained from NC6 (no Ca ${ }^{2+}, 10^{6}$ cells $\left./ \mathrm{mL}\right)(p=0.0324)$ and C6 (with $\mathrm{Ca}^{2+}, 10^{6}$ cells/ $\mathrm{mL})(p<0.0001)$. A pronounced decrease in $\mathrm{Ca}^{2+}$ response $(p=0.0006)$ was observed in NC6 when the detection was carried out in the $\mathrm{Ca}^{2+}$ and $\mathrm{Mg}^{2+}$-free solution as compared to $\mathrm{C} 6$, where the $\mathrm{Ca}^{2+}$ and $\mathrm{Mg}^{2+}$ were present in the solution.

Detection of $E$. coli $\mathrm{O}_{157: \mathrm{H}_{7}}$ in pure culture. The developed B cell biosensor was evaluated for the detection of E. coli O157:H7 ranging from $10^{1}$ to $10^{5} \mathrm{CFU} / \mathrm{mL}$ in pure culture. The control measurement was carried out using HBSS to replace E. coli O157:H7. Comparing to the control, the means of the ratio were significantly different when the concentration of $E$. coli $\mathrm{O} 157: \mathrm{H} 7$ varies from $10^{2}-10^{5} \mathrm{CFU} / \mathrm{mL}$. As shown in Fig. 3a the ratio was found to increase linearly with the increase of the number of bacteria presented in the solution from $10^{1}$ to $10^{3} \mathrm{CFU} / \mathrm{mL}$. A calibration curve was fitted by linear regression, yielding $\mathrm{Y}=0.0565 \mathrm{X}+0.6753\left(\mathrm{R}^{2}=0.96\right)$. When equivalent amounts of extracted LPS were used to stimulate the $\mathrm{B}$ cell $\left(10^{1}-10^{7} \mathrm{CFU} / \mathrm{mL}\right)$, the linear relation between the amount of LPS and the ratio was observed (Fig. 3b). A calibration curve was fitted by linear regression, yielding $\mathrm{Y}=0.03183 \mathrm{X}+0.6532\left(\mathrm{R}^{2}=0.83\right)$. 

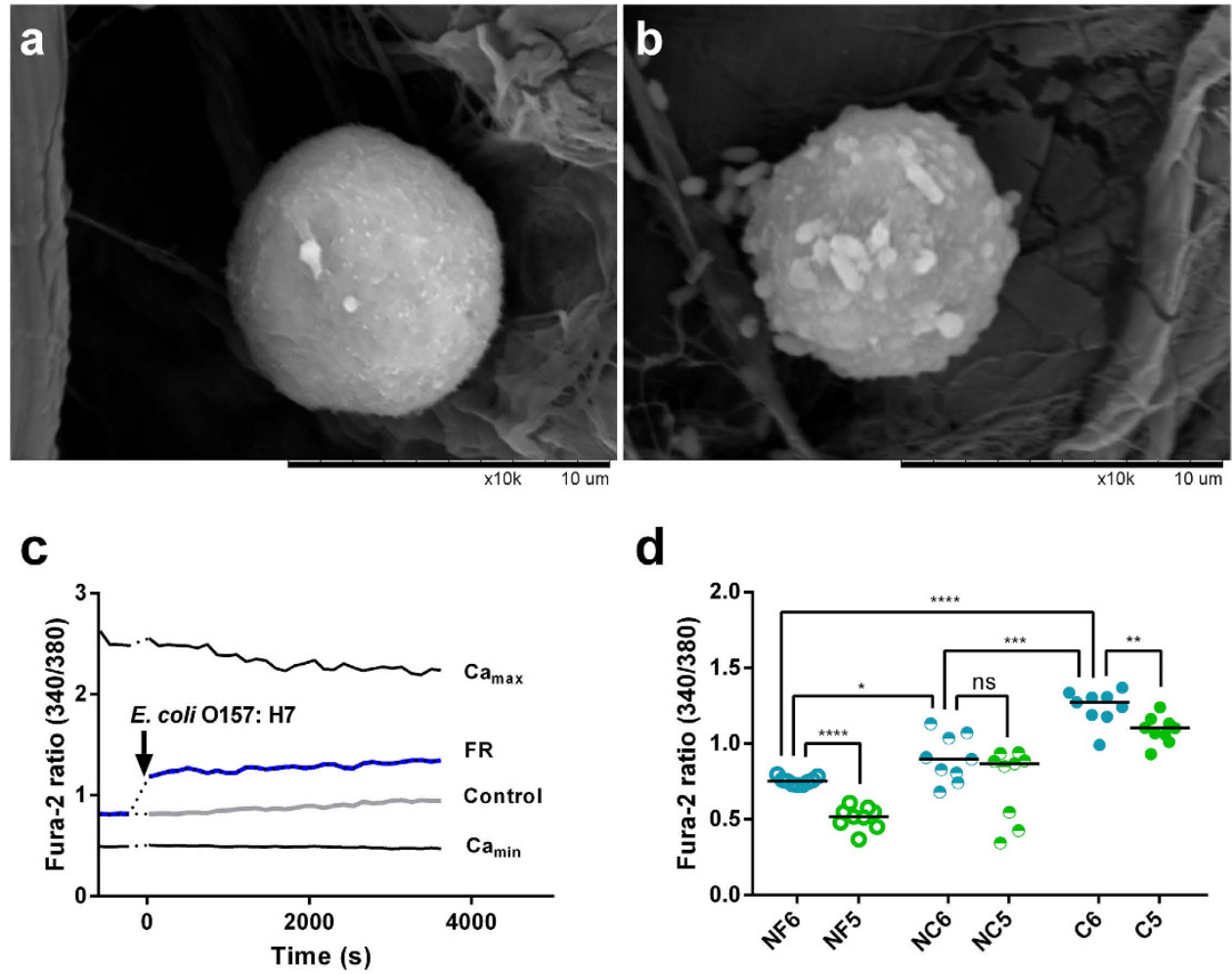

Figure 2. Optimization of the B cell biosensor. (a). SEM image of a B cell in the absence of any bacteria $(\times 10000)$. (b). SEM image of a B cell with E.coli O157:H7 cells $(\times 10000)$. (c). Real time response profile of Fura-2 340/380 ratio. (d). Comparison of the Fura-2 ratio for each group defined in the text. Data points represent the ratio of the stimulation by each concentration of E. coli O157:H7 $\left(10^{1}-10^{9} \mathrm{CFU} / \mathrm{mL}\right)$ in the group at the same time. Bars indicate the medians and $p$-value obtained by paired $\mathrm{t}$-test. (two-tailed, ${ }^{\mathrm{ns}} p>0.05,{ }^{*} p<0.05,{ }^{* *} p<0.01,{ }^{* *} p<0.001,{ }^{* * *} p<0.0001, \mathrm{n}=9$ ) NF6: B cells (no Fura-2, $\mathrm{Ca}^{2+}{\text { and } \mathrm{Mg}^{2+}}^{* *}$ HBSS), $10^{6}$ cells/mL. NF5: B cells (no Fura-2, $\mathrm{Ca}^{2+}$ and $\mathrm{Mg}^{2+} \mathrm{HBSS}$ ), $10^{5}$ cells/mL. NC6: B cells (Fura-2, $\mathrm{Ca}^{2+}$ and $\mathrm{Mg}^{2+}$-free HBSS), $10^{6}$ cells/mL. NC5: B cells (Fura-2, $\mathrm{Ca}^{2+}$ and $\mathrm{Mg}^{2+}$-free HBSS), $10^{5}$ cells/mL. C6: B cells (Fura-2, $\mathrm{Ca}^{2+}$ and $\mathrm{Mg}^{2+} \mathrm{HBSS}$ ), $10^{6}$ cells/mL. C5: B cells (Fura-2, $\mathrm{Ca}^{2+}$ and $\mathrm{Mg}^{2+} \mathrm{HBSS}$ ), $10^{5}$ cells/ $\mathrm{mL}$.

Selective detection of E. coli O157:H7 is necessary for use of the biosensor in food safety. Therefore, the abilities of the B cell biosensor to detect target organisms and non-target organisms were determined by the inclusivity test and the exclusivity test, respectively. Eight strains of $E$. coli comprising 2 different serogroups (O157 and non-O157) were tested, and seven of the strains, except for EHEC (non-O157), were sensitive for the detection in inclusivity tests. Exclusivity tests using 7 strains from 6 distinct different genera showed high specificity (Fig. 3c). p-values of the results of inclusivity and exclusivity tests are shown in Supplementary Table S5.

Listeria monocytogenes, $S$. Typhimurium and $V$. parahaemolyticus were chosen as representative bacteria in exclusivity tests, because this B cell was constructed to produce monoclonal antibodies (MAbs) specific for the LPS of E. coli O157 and group N Salmonella for use as highly specific diagnostic reagents. Bio X cell (West Lebanon, NH, USA) has developed anti-mouse IgM isotype control (Catalog number: BE0087) using B cell MARC 29F8. Mabs 29F8 was core antigen specific and also was determined to react with the LPS core antigen on the basis of its reactivity with the 12 - to 16 -kDa bands of the aqueous-phase $\mathrm{LPS}^{47}$. L. monocytogenes and $V$. parahaemolyticus were used as the representatives of Gram-positive and Gram-negative bacteria respectively. As to $S$. Typhimurium, it was used to test the specificity of this biosensor to O-antigen. The polysaccharides of group N Salmonella such as S. godesberg belong to chemotype VI (basal sugars with additional galactosamine and fucose). S. Typhimurium belongs to group D (polysaccharides chemotype XVI: basal sugars with additional mannose, rhamnose and tyvelose) ${ }^{48}$.

The accuracy of this sensor was evaluated quantitatively by Receiver Operating Characteristic (ROC) curve (Fig. 3d). The ratios of Fura-2 in the presence of E. coli O157:H7 ATCC 43888 at different concentrations respectively were detected continuously for $30 \mathrm{~min}$, and each concentration was repeated three times. The collected data was used to obtain the ROC curve. The accuracy of the detection as represented by the area under ROC (AUR) curves was determined to be $0.7319,0.7690,0.8484,0.7817$ and 0.7885 , respectively, for the concentrations of $E$. coli $\mathrm{O} 157: \mathrm{H} 7$ from $10^{1}, 10^{2}, 10^{3}, 10^{4}$ to $10^{5} \mathrm{CFU} / \mathrm{mL}$. All values of AUR obtained from different concentrations of $E$. coli $\mathrm{O} 157: \mathrm{H} 7$ were greater than 0.7 in a range of 

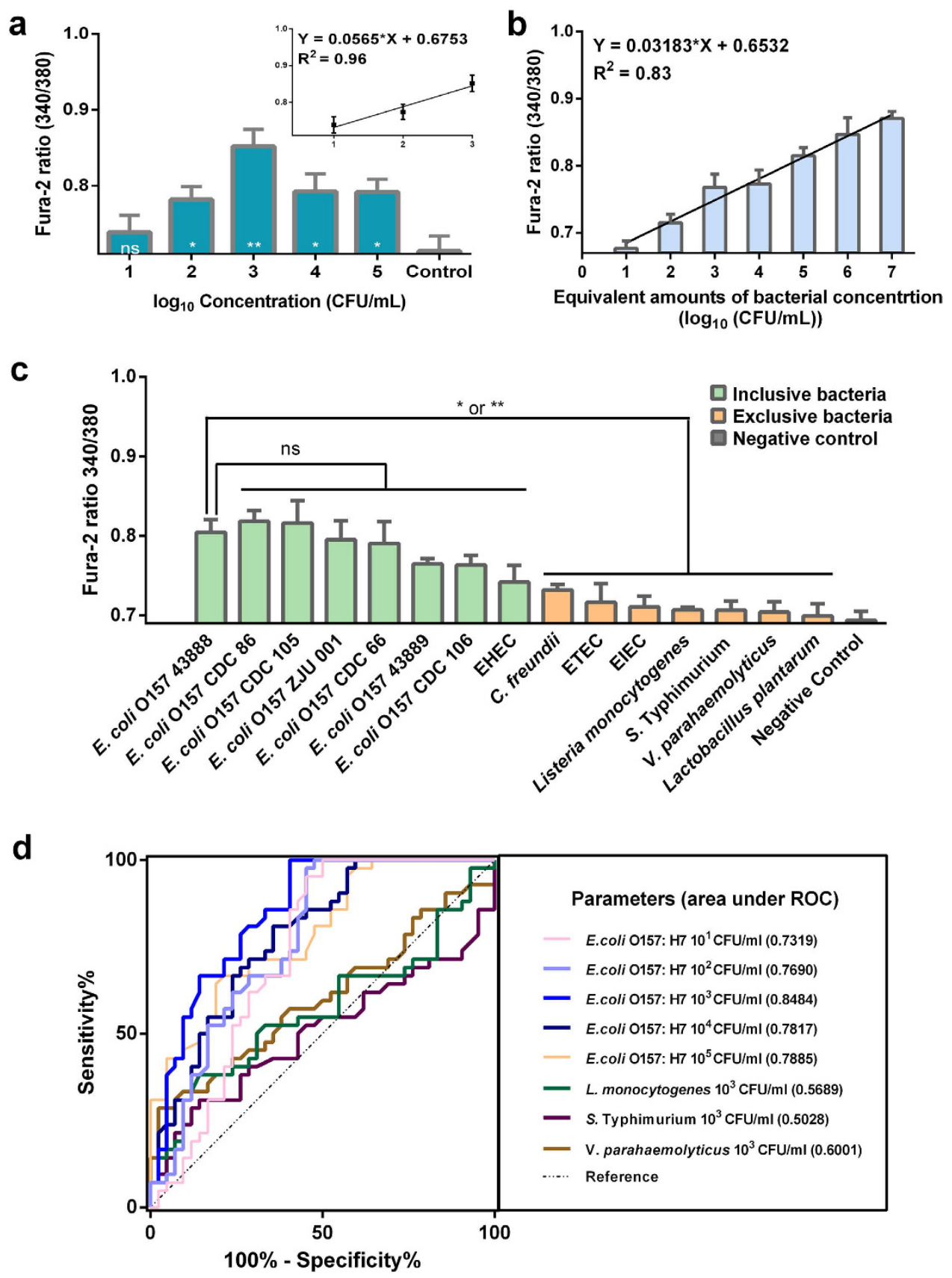

Figure 3. Detection of E. coli O157:H7 in pure culture. (a). Plot of the biosensor's response, Fura-2 ratios, to different concentrations of $E$. coli $\mathrm{O} 157: \mathrm{H} 7$ in pure culture. Insert: Linear calibration curve obtained for E. coli $\mathrm{O} 157: \mathrm{H} 7$ in the range of concentrations from $10^{1}$ to $10^{3} \mathrm{CFU} / \mathrm{mL}$. All data shown is mean \pm s.e.m. and $p$-value obtained by unpaired t-test. (two-tailed, ${ }^{n s} p>0.05,{ }^{*} p<0.05,{ }^{* *} p<0.01, \mathrm{n}=4$ ). (b). Plot of the biosensor's response, Fura-2 ratios, to different concentrations of LPS extracted from E. coli O157:H7 which is equal to bacterial concentrations from $10^{1}$ to $10^{7} \mathrm{CFU} / \mathrm{mL}$. All data shown is mean \pm s.e.m. and $p$-value obtained by unpaired t-test. (two-tailed, ${ }^{\mathrm{n} s} p>0.05,{ }^{\star} p<0.05,{ }^{* *} p<0.01, \mathrm{n}=3$ ). (c). Inclusivity tests and exclusivity tests to compare the B cell biosensor's response to target and non-target bacteria species at $10^{3}$ $\mathrm{CFU} / \mathrm{mL}$. All data shown is mean \pm s.e.m. and $p$-value obtained by unpaired t-test. (two-tailed, ${ }^{\mathrm{ns}} p>0.05$, ${ }^{\star} p<0.05,{ }^{* *} p<0.01, \mathrm{n}=3$ ). (d). ROC curves for all sensitivity sets and specificity sets with three replicates in bacteria pure culture conducted continuously for $30 \mathrm{~min}$.

0.7319 to 0.8484 , indicating that the $\mathrm{B}$ cell biosensor was accurate in the detection range. It is observed that AUR value dropped to 0.7817 and 0.7885 when the concentration of E. coli $\mathrm{O} 157: \mathrm{H} 7$ increased to $10^{4} \mathrm{CFU} / \mathrm{mL}$ and $10^{5} \mathrm{CFU} / \mathrm{mL}$, respectively. When $10^{3} \mathrm{CFU} / \mathrm{mL}$ L. monocytogenes, S. Typhimurium, and $V$. parahaemolyticus were tested, the AUR values dropped to $0.5689,0.5028$ and 0.6001 , respectively. 
a

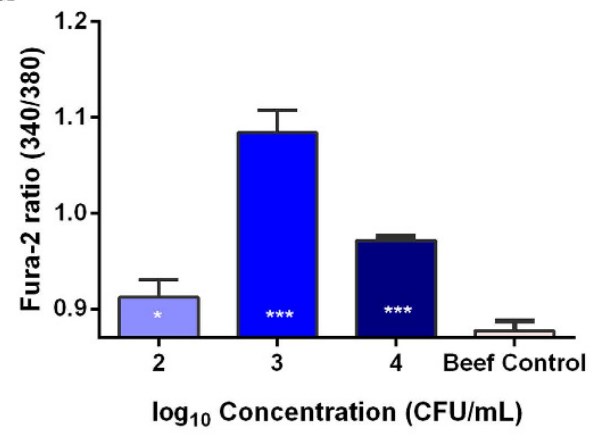

b

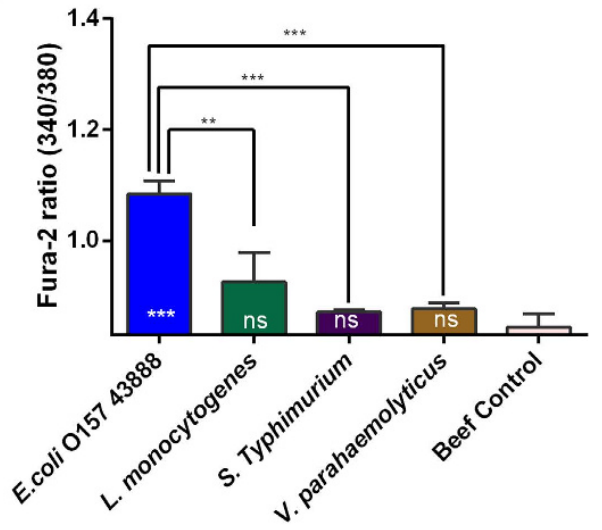

Figure 4. Detection of E. coli O157:H7 in ground beef. (a). Plot of the biosensor's response, Fura-2 ratio, to different concentrations of $E$. coli O157: $\mathrm{H} 7$ in ground beef. All data shown is mean \pm s.e.m. and $p$-value obtained by unpaired t-test. (two-tailed, ${ }^{\star} p<0.05,{ }^{* *} p<0.001, \mathrm{n}=3$ ). (b). Biosensor's response to different pathogens with the same concentration of $10^{3} \mathrm{CFU} / \mathrm{mL}$ in ground beef. All data shown is mean \pm s.e.m. and $p$-value obtained by unpaired t-test. (two-tailed, ${ }^{\mathrm{ns}} p>0.05,{ }^{* *} p<0.01,{ }^{* * *} p<0.001, \mathrm{n}=3$ )

Detection of $E$. coli $\mathrm{O}_{157}: \mathrm{H}_{7}$ in ground beef. The B cell biosensor was further evaluated with bacteria inoculated ground beef extract samples. Based on the experiments performed using pure culture, we chose ground beef extract that were inoculated with $10^{2} \mathrm{CFU} / \mathrm{mL}, 10^{3} \mathrm{CFU} / \mathrm{mL}$ and $10^{4} \mathrm{CFU} / \mathrm{mL}$ E. coli $\mathrm{O} 157: \mathrm{H} 7$ for the test. The B cells' response to the ground beef extract inoculated with E. coli O157:H7 ATCC 43888 exhibited a similar response to the pure culture. A control measurement was carried out in the absence of E. coli O157:H7. As shown in Fig. 4a, significant differences, as compared to a control, were observed when the E. coli O157:H7 concentrations varied from $10^{2}-10^{4} \mathrm{CFU} / \mathrm{mL}(p=0.0420$, 0.0002 and 0.0001 respectively).

L. monocytogenes, S. Typhimurium and $V$. parahaemolyticus were used in ground beef samples as non-target bacteria to evaluate the specificity of the biosensor. As shown in Fig. $4 \mathrm{~b}$, when the same concentration $\left(10^{3} \mathrm{CFU} / \mathrm{mL}\right)$ of different pathogen was detected, the ratio of the sample with E. coli O157:H7 was extremely significant compared to the control $(p=0.0002)$, but ratios of Fura-2 with non-target bacteria weren't found the significant differences compared to the control $(p>0.05)$ in the ground beef extract samples. The very significant difference between the detection of E. coli O157:H7 and L. monocytogenes was found ( $p=0.0095)$, and the extremely significant differences between the detection of $E$. coli O157:H7 and S. Typhimurium and V. parahaemolyticus were found ( $p=0.0001$ and 0.0002 respectively).

\section{Discussion}

The proposed $\mathrm{Ca}^{2+}$ indicator based B cell biosensor for detecting E. coli O157:H7 with better combined detection time and sensitivity was conceived, tested and validated in this study. BCR-induced $\mathrm{Ca}^{2+}$ flux can be triggered in seconds, and the Ca influx will happen instantly ${ }^{29}$, leading to Fura- $2\left(\mathrm{a} \mathrm{Ca}^{2+}\right.$ sensitive divalent metal ion chelator) complexing with $\mathrm{Ca}^{2+33}$, all of them happened in a very short time. In the optimization of the B cell biosensor, our data suggested that the non-subtracted ratios obtained from the earlier time would be more accurately correlated to E. coli O157:H7. To determine the optimum time for the detection, the ratio of FR obtained from the different time was subtracted by the ratio of Control at the same time. It was found that after four to six min the response signal became stable. Thus, the ratio at $10^{\text {th }} \mathrm{min}$ was used as a detection ratio in the subsequent experiments. ROC curves drawn using the data collected from continuous $30 \mathrm{~min}$ in the bacterial pure culture (Fig. $3 \mathrm{~d}$ ) showed the same results as that at the $10^{\text {th }} \mathrm{min}$.

From Fig. 2d, it is very clear that the B cells with the higher concentration combined with relatively the same concentration of $E$. coli $\mathrm{O} 157: \mathrm{H} 7$ had higher ratio produced by autofluorescence signal of bacteria, and the ratio produced by the autofluorescence of B cells without loading Fura- 2 combined with E. coli $\mathrm{O} 157: \mathrm{H} 7$ had significant differences from the ratio produced by the B cells loaded with Fura-2 when the detection solution was with or without $\mathrm{Ca}^{2+}$ and $\mathrm{Mg}^{2+}$. Considering the previous result obtained from the comparison between group NC5 and NC6, these data divulged that a proportion of the total BCR induced $\mathrm{Ca}^{2+}$ flux observed is due to extracellular $\mathrm{Ca}^{2+}$ influx. The previous research on $\mathrm{CD} 20$ induced cytosolic $\mathrm{Ca}^{2+}$ flux also indicated a proportion of the total $\mathrm{Ca}^{2+}$ flux observed is due to extracellular $\mathrm{Ca}^{2+}$ influx in $\mathrm{B}$ cells ${ }^{49}$. The aforementioned results showed that the autofluorescence signal from the organism was negligible in comparison with the Fura-2 response signal. The higher response signal could be obtained from the higher concentrations of the $\mathrm{B}$ cells because more $\mathrm{Ca}^{2+}$ influx from the extracellular would increase the ratio, which would increase the biosensor sensitivity. Therefore, $10^{6}$ cells/ $\mathrm{mL} B$ cells loaded with Fura-2 in the solution with $\mathrm{Ca}^{2+}$ were used in the later tests. 
In the detection of E. coli $\mathrm{O} 157: \mathrm{H} 7$ in pure culture, the B cell biosensor provided an increasing signal response which is linear in relation to the logarithm of E. coli O157:H7 concentration $\left(10^{1}-10^{3} \mathrm{CFU} /\right.$ $\mathrm{mL})$. The ratio began to drop when the concentration of E. coli $\mathrm{O} 157: \mathrm{H} 7$ was $10^{4} \mathrm{CFU} / \mathrm{mL}$ and $10^{5}$ $\mathrm{CFU} / \mathrm{mL}$, probably because the high number of $E$. coli cells triggered the B cell expansion and apoptosis $^{50}$, subsequently BCR-induced $\mathrm{Ca}^{2+}$ signaling was interfered. To verify it, the equivalent amounts of extracted LPS from E. coli O157:H7 were detected by this B cell biosensor. As shown in Fig. 3a, the ratio increased linearly with an increase of the equivalent amounts of LPS $\left(10^{1}-10^{7} \mathrm{CFU} / \mathrm{mL}\right)$. It is consistent with a recent study showing the ability of $\mathrm{B}$ cells to present antigen-derived peptides to $\mathrm{T}$ cells was also dependent on the amount of antigen tethered on the membrane ${ }^{51}$.

In the selective detection of $E$. coli $\mathrm{O} 157: \mathrm{H} 7$ in pure culture, our results showed that nonspecific binding did not lead to significant increase in the ratio with respect to the control in this B cell biosensor. Our results also showed that the MAbs on the surface of B cells are specific to O-antigen and the LPS of Gram-negative bacteria, which might have caused less response to EHEC (non-O157) and Gram-positive bacteria such as L. monocytogenes and Lactobacillus plantarum, respectively. In Fig. 3c, the statistical analysis of $p$-values (based on t-test) shows significant differences between inclusive bacteria and exclusive bacteria (Supplementary Table S5), however, it is recognized that the signal of all E. coli O157:H7 in the inclusivity test may need to be further amplified to ensure the true positive or true negative results for real food sample testing.

Based on ROC curve in Fig. 3d, it is quite evident that the B cell biosensor has a good specificity and its detection is reproducible and the ratio obtained from the $10^{\text {th }} \mathrm{min}$ could represent the results obtained from $10 \mathrm{~min}$ to $30 \mathrm{~min}$ during the detection. Since there was no significant difference as compared to the control when E. coli $\mathrm{O} 157: \mathrm{H7}$ concentration was $10^{1} \mathrm{CFU} / \mathrm{mL}$, the detection range of the biosensor for E. coli $\mathrm{O} 157: \mathrm{H} 7$ was $10^{2}-10^{5} \mathrm{CFU} / \mathrm{mL}$.

For the detection of bacteria in the pure culture, this B cell biosensor had a detection limit of $5.9 \times 10^{2}$ $\mathrm{CFU} / \mathrm{mL}$. An additional feature of this biosensor is its rapid analysis time of $10 \mathrm{~min}$. It is shorter than most biosensing methods which have the detection limits in the range of $10^{2}$ to $10^{4} \mathrm{CFU} / \mathrm{mL}$, such as surface plasmon resonance $(\mathrm{SPR})^{52}$, enzyme-linked immunosorbent assay (ELISA) ${ }^{53}$, fiber optic ${ }^{54}$ and quartz crystal microbalance $(\mathrm{QCM})^{55}$. E. coli $\mathrm{O} 157: \mathrm{H7}$ bacteria as low as 7 CFU were detected on the screen-printed carbon electrode (SPCE) sensor in $70 \mathrm{~min}^{56}$, and $10 \mathrm{CFU} / \mathrm{mL}$ were detected by the long-range surface plasmon-enhanced fluorescence spectroscopy (LRSP-FS) in $40 \mathrm{~min}^{57}$. There are also some biosensors with a low detection limit and a short detection time, such as $67 \mathrm{CFU} / \mathrm{mL}$ were detected by a lateral-flow immunobiosensor based on electrospun nanofibers and conductive magnetic nanoparticles (MNPs) in $8 \mathrm{~min}^{58}, 500 \mathrm{CFU} / \mathrm{g}$ in lettuce were also detected by CANARY (cellular analysis and notification of antigen risks and yields) sensor in less than $5 \mathrm{~min}^{11}$. In this study, since only $30 \mu \mathrm{L}$ test sample was used in each well for detection, the B cell biosensor was actually able to detect 18 cells of $E$. coli O157:H7. If some concentration procedures were applied in sample preparation, the detection limit of the B cell biosensor could be further improved to the level of several cells per $\mathrm{mL}$. This biosensor can be easily operated in sample handling and preparation for multiplex tests, which has the potential for rapid, high throughput detection of foodborne pathogens.

For the detection of bacteria in ground beef, this $\mathrm{B}$ cell biosensor had a detection limit of $8.6 \times 10^{2}$ $\mathrm{CFU} / \mathrm{mL}$ (26 CFU in $30 \mu \mathrm{L}$ test sample) responding to E. coli O157:H7 in the ground beef extract sample. According to the statistical analysis, the specificity significance of target and non-target bacteria detected in the pure culture and the ground beef are slightly different. It may be due to food particulates and high levels of background microbiota from beef extract affectted the sensitivity of this B cell biosensor.

The advantages of the rapid response to the antigen of $\mathrm{B}$ cell and the sensitivity to $\mathrm{Ca}^{2+}$ of Fura-2 were combined to develop this $\mathrm{Ca}^{2+}$-indicator based $\mathrm{B}$ cell biosensor which successfully detected $E$. coli $\mathrm{O} 157: \mathrm{H7}$ at a low detection limit and in short time in both pure culture and ground beef. The main hurdle that remains is that the $\mathrm{B}$ cells themselves are not comparably 'stable' to other biosensing elements such as antibodies or nucleic acid probes. The signal response varies from batch to batch, and is influenced mainly by the cell's viability, cell concentration and the exposing time after loading Fura-2. To overcome this hurdle, freshly prepared B cells are preferred, and the controls need to be employed for each batch test.

In summary, B cell MARC $29 \mathrm{f} 8$ loaded with $\mathrm{Ca}^{2+}$-indicator Fura-2 was successfully developed as a convenient and sensitive biosensor. By using E. coli O157:H7 as a model target pathogen, the target bacteria were detected by measuring the intracellular $\mathrm{Ca}^{2+}$ concentration caused by BCR induced $\mathrm{Ca}^{2+}$ flux. This B cell based biosensor combined the properties of the sensitivity to $\mathrm{Ca}^{2+}$ of Fura- 2 and the rapid response to the antibody of $\mathrm{B}$ cells.

The results showed that the responses of the developed B cell biosensor were sensitive and specific with a detection limit as low as $10^{2} \mathrm{CFU} / \mathrm{mL}$ in both pure culture and ground beef within $10 \mathrm{~min}$. The combination of the fluorescently loaded B cells specifically against E. coli O157:H7 and a microplate reader will pave the way for designing $B$ cell based biosensors with features of easy operation, low-cost and high throughput for food detection of pathogens in food safety, biosafety, clinical diagnostics and environmental monitoring. 


\begin{abstract}
Methods
Reagents. Dulbecco's modified Eagle's medium (DMEM), Dulbecco's modified Eagle's medium without phenol red (DMEM without PR), heat-inactivated fetal bovine serum (FBS), Hank's balanced salt solution (HBSS), $\mathrm{Ca}^{2+}$ and $\mathrm{Mg}^{2+}$-free HBSS, MEM non-essential amino acids (MEM NAA), 0.4\% Trypan Blue Solution, Fura-2/AM and 0.5 M EDTA were purchased from Life Technologies (Carlsbad, CA, USA). All bacteria culture mediums were purchased from BD (Sparks, MD, USA). Goat antimouse IgM-HRP (horseradish peroxidase), Lipopolysaccharide (LPS) extraction kit and silver staining kit were obtained from AbD (AbD Serotec, USA), Intron Biotechnology (Gyeonggi-do, Korea) and Sangon Biotech (Shanghai, China), respectively. All other reagents were obtained from Sigma (St. Louis, MO, USA). All solutions and buffers used in this study were prepared in sterile de-ionized (DI) water from Millipore Direct-8 system (Billerica, MA, USA).
\end{abstract}

B cell lines and culture conditions. The B cell line MARC 29F8 was obtained from ATCC (American Type Culture Collection, Manassas, VA; ATCC number CRL-2508). The organism of this B cell line is mouse, cell type is hybridoma B lymphocyte, and isotype is IgM. It was routinely cultured in DMEM supplemented with $4 \mathrm{mM}$ L-glutamine adjusted to contain $1.5 \mathrm{~g} / \mathrm{L}$ sodium bicarbonate, $4.5 \mathrm{~g} / \mathrm{L}$ glucose, 1 vol $\%$ MEM NAA and $10 \%$ heat-inactivated FBS. The cells were cultured at $37^{\circ} \mathrm{C}$ in a humid atmosphere containing 7\% $\mathrm{CO}_{2}$. Liquid-nitrogen-stored MARC 29F8 cells (passage numbers between 5 and 10) were suspended at a ratio of 1:10 in the complete medium and grown for $72 \mathrm{~h}$. MARC 29F8 cells were passaged again in DMEM with or without phenol red supplemented with $10 \%$ heat-inactivated FBS in T-25 and T-75 flasks (Falcon, Oxnard, USA) until they reached to a logarithmic phase of growth (usually $72 \mathrm{~h}$ ) after which they were used for experiments. The cell count was performed using a TC10 Automated Cell Counter (Bio-Rad, Hercules, CA, USA) according to the manufacturer's instructions.

Bacterial strains and culture conditions. Bacterial strains used in this study were obtained from the American Type Culture collection (ATCC), China Center of Industrial Culture Collection (CICC), China National Center for Medical Culture Collections (CMCC), the Chinese Zhejiang Center for Disease Control and Prevention (Zhejiang Province CDC) and Zhejiang University (ZJU). The detailed informations are shown in Supplementary Table S1 and Table S2.

Lactobacillus plantarum and other strains were grown on MRS broth and $\mathrm{BHI}$ broth at $37^{\circ} \mathrm{C}$, respectively. Listeria monocytogenes and other strains were cultured $48 \mathrm{~h}$ and $24 \mathrm{~h}$, respectively. The concentration of bacteria in this study was determined in triplicate by enumeration on Trypticase Soy Agar (TSA). The detailed information is described in the Supplementary Information.

Scanning electron microscopy (SEM) imaging SEM samples were prepared (see the Supplementary Information) and imaged using a Hitachi TM1000 scanning electron microscope (SEM) (Hitachi, Japan).

Preparation of a B cell biosensor. The B cell biosensor was constructed under sterile conditions by preparing $\mathrm{B}$ cells loaded with $\mathrm{Ca}^{2+}$-indicator Fura-2, with a slight modification to the measurement of $\left[\mathrm{Ca}^{2+}\right]_{\mathrm{i}}$ in whole cell suspensions using Fura- $2^{33}$. In brief, for fluorescent $\mathrm{Ca}^{2+}$ flux experiment, undifferentiated MARC 29F8 cells were harvested in DMEM without PR and incubated at $37^{\circ} \mathrm{C}$ for $5 \mathrm{~min}$. B cells were washed three times in HBSS after DMEM (without PR) was removed. Then the cell suspensions were incubated with $4.5 \mathrm{nmol}$ of Fura-2/AM per $10^{6}$ cells for $30 \mathrm{~min}$ at $37^{\circ} \mathrm{C}$ in the dark and the cells sediment were resuspended in $30 \mathrm{~mL}$ HBSS buffer. After incubating for an additional $15 \mathrm{~min}$ at room temperature in the dark to allow for the de-esterification of the Fura-2/AM, the cells were sedimented, and then split and resuspended in $30 \mathrm{~mL}$ of HBSS buffer and $\mathrm{Ca}^{2+}$ and $\mathrm{Mg}^{2+}$-free $\mathrm{HBSS}$ buffer twice respectively.

Detection of $E$. coli O157: $\mathrm{H}_{7}$ in pure culture. Briefly, a portion of $30 \mu \mathrm{l}$ Fura-2 loaded MARC 29F8 $\mathrm{B}$ cells were added into each well of a 96-well plate, and then $30 \mu \mathrm{l}$ analytes were loaded into the wells. To assess dynamic ranges for the microplate reader, maximum and minimum fluorescence values (at 340 and $380 \mathrm{~nm}$ excitation wavelengths) were determined in separate experiments in which Fura-2 loaded MARC 29F8 cells were incubated with $0.1 \%$ Triton X-100 and $4.5 \mathrm{mM}$ ethylenediamine-tetraacetic acid (EDTA), respectively. Fluorescence was evoked by 340- and 380-nm excitation wavelengths (F340 and F380) and collected at $510 \mathrm{~nm}$ using Synergy H1 Hybrid Multi-Mode Microplate reader (BioTek, Winooski, VT, USA). Data was collected every $120 \mathrm{~s}$ in the plate reader. Data from all measurements were presented as 340/380 fluorescence ratios directly representative of changes in intracellular $\mathrm{Ca}^{2+30}$. E. coli O157:H7 ATCC 43888 was serially diluted in HBSS from $6.2 \times 10^{1}$ to $6.2 \times 10^{9}$ and from $5.9 \times 10^{1}$ to $5.9 \times 10^{5}$ in the optimization test and the accuracy test, respectively.

Equivalent amounts of extracted LPS from E. coli O157:H7 ATCC 43888 were used to verify the linear relation between the bacterial concentration and the response of the $\mathrm{B}$ cell biosensor. The detailed information is described in the Supplementary Information.

Totally, 8 strains and 7 strains at the bacterial concentration of $10^{3} \mathrm{CFU} / \mathrm{mL}$ were used for inclusivity tests and exclusivity tests, respectively (Supplementary Table S1 and Table S2). E. coli O157:H7 ATCC 43888 and HBSS without any bacteria were added into Fura-2 loaded B cells as the positive control and 
negative control, respectively. The sensor response to different concentrations of bacteria was calculated as the mean value of ratios measured in three independent tests.

Detection of $E$. coli $\mathrm{O}_{157}: \mathrm{H}_{7}$ in ground beef. To validate the developed B cell biosensor, experiments were conducted using ground beef extract. The ground beef were purchased from a local grocery store, and contaminated with three different concentrations of E. coli O157:H7 to mimic bacterial contamination. Twenty-five grams of ground beef was mixed with $225 \mathrm{ml}$ of HBSS in Filtra bags (Labplas Inc., Quebec, Canada) and stomached with Stomacher 400 (Seward, Norfolk, UK) for $1 \mathrm{~min}$. Then the washing solution was collected. One milliliter of E. coli O157:H7 cells at dilutions of $10^{3}, 10^{4}$, and $10^{5}$ $\mathrm{CFU} / \mathrm{mL}$ was added to $9 \mathrm{ml}$ of washing solution of the ground beef sample, to obtain the ground beef samples contaminated with E. coli $\mathrm{O} 157: \mathrm{H} 7$ at $10^{2}, 10^{3}$, and $10^{4} \mathrm{CFU} / \mathrm{mL}$. Then the same procedure for detection of E. coli O157:H7 in HBSS was followed using the prepared ground beef extract samples. The Fura-2 loaded B cells in the ground beef extract sample were used as a control for the test.

Statistical analysis. Data represents mean \pm s.e.m. (standard error of the means) of three experiments. The data were analyzed by GraphPad Prism software (GraphPad, San Diego, CA). Paired t-test was used in section Optimization of the $\mathbf{B}$ cell biosensor to analyze the differences between two groups which were both added with nine different concentrations of E. coli O157: H7 respectively. Unpaired $\mathrm{t}$-test was used in the rest of experiments to analyze the differences between two groups which were added with the same concentration of bacterial pathogens. $p<0.05$ were considered significant.

\section{References}

1. Scallan, E. \& Mahon, B. E. Foodborne Diseases Active Surveillance Network (FoodNet) in 2012: a foundation for food safety in the United States. Clin. Infect. Dis. 54 Suppl 5, S381-384 (2012).

2. Scallan, E., Griffin, P. M., Angulo, F. J., Tauxe, R. V. \& Hoekstra, R. M. Foodborne illness acquired in the United Statesunspecified agents. Emerg. Infect. Dis. 17, 16-22 (2011)

3. Scallan, E. et al. Foodborne illness acquired in the United States-major pathogens. Emerg. Infect. Dis. 17, 7-15 (2011).

4. Scharff, R. L. Economic burden from health losses due to foodborne illness in the United States. J. Food Prot. 75, 123-131 (2012).

5. Arnandis-Chover, T. et al. Detection of food-borne pathogens with DNA arrays on disk. Talanta 101, 405-412 (2012).

6. Stacy M. Crim et al. Incidence and trends of infection with pathogens transmitted commonly through food - Foodborne diseases active surveillance network, 10 U.S. Sites, 2006-2013. Morb. Mortal. Weekly Rep. 63, 328-332 (2014).

7. Arora, P., Sindhu, A., Dilbaghi, N. \& Chaudhury, A. Biosensors as innovative tools for the detection of food borne pathogens. Biosens. Bioelectron. 28, 1-12 (2011).

8. Rawson, D. M., Willmer, A. J. \& Turner, A. P. Whole-cell biosensors for environmental monitoring. Biosensors 4, 299-311 (1989).

9. Neufeld, T. et al. Genetically engineered $p f a b A$ pfabR bacteria: an electrochemical whole cell biosensor for detection of water toxicity. Anal. Chem. 78, 4952-4956 (2006).

10. Fine, T. et al. Luminescent yeast cells entrapped in hydrogels for estrogenic endocrine disrupting chemical biodetection. Biosens. Bioelectron. 21, 2263-2269 (2006).

11. Rider, T. H. et al. A B cell-based sensor for rapid identification of pathogens. Science 301, 213-215 (2003).

12. May, K. M., Wang, Y., Bachas, L. G. \& Anderson, K. W. Development of a whole-cell-based biosensor for detecting histamine as a model toxin. Anal. Chem. 76, 4156-4161 (2004).

13. Meng, Y. et al. Continuous, noninvasive monitoring of local microscopic inflammation using a genetically engineered cell-based biosensor. Lab. Invest. 85, 1429-1439 (2005).

14. Liu, Q. et al. Detection of heavy metal toxicity using cardiac cell-based biosensor. Biosens. Bioelectron. 22, 3224-3229 (2007).

15. Banerjee, P., Lenz, D., Robinson, J. P., Rickus, J. L. \& Bhunia, A. K. A novel and simple cell-based detection system with a collagen-encapsulated B-lymphocyte cell line as a biosensor for rapid detection of pathogens and toxins. Lab. Invest. 88, 196-206 (2008).

16. Banerjee, P. \& Bhunia, A. K. Mammalian cell-based biosensors for pathogens and toxins. Trends Biotechnol. 27, 179-188 (2009).

17. Cheran, L.-E., Cheung, S., Wang, X. \& Thompson, M. Probing the bioelectrochemistry of living cells. Electrochim. Acta 53, 6690-6697 (2008).

18. East, A. K., Mauchline, T. H. \& Poole, P. S. Biosensors for ligand detection. Adv. Appl. Microbiol. 64, 137-166 (2008).

19. Haruyama, T. Cellular biosensing: Chemical and genetic approaches. Anal. Chim. Acta 568, 211-216 (2006).

20. Kintzios, S. E. Cell-based biosensors in proteomic analysis. Front. Drug Des. Discovery 2, 225-239 (2005).

21. Kovacs, G. T. Electronic sensors with living cellular components. P. IEEE 91, 915-929 (2003).

22. Roche, S. M. et al. Assessment of the virulence of Listeria monocytogenes: agreement between a plaque-forming assay with HT29 cells and infection of immunocompetent mice. Int. J. Food Microbiol. 68, 33-44 (2001).

23. Curtis, T., Naal, R. M. Z., Batt, C., Tabb, J. \& Holowka, D. Development of a mast cell-based biosensor. Biosens. Bioelectron. 23, 1024-1031 (2008).

24. Lin, B., Li, P. \& Cunningham, B. T. A label-free biosensor-based cell attachment assay for characterization of cell surface molecules. Sensor. Actuat. B-Chem. 114, 559-564 (2006).

25. Stoddart, A. et al. Lipid rafts unite signaling cascades with clathrin to regulate BCR internalization. Immunity 17, 451-462 (2002).

26. Bhunia, A. \& Westbrook, D. Alkaline phosphatase release assay to determine cytotoxicity for Listeria species. Lett. Appl. Microbiol. 26, 305-310 (1998)

27. Rider, T. CANARY sensor for rapid, sensitive identification of pathogens. Bio. Micro. and Nanosystems Conference: BMN'06, San Francisco. New York, USA: IEEE. (2006, Jan. 15-18)

28. Petrovick, M. S. et al. Rapid sensors for biological-agent identification. Lincoln Lab. J. 17, 63-84 (2007).

29. King, L. B. \& Freedman, B. D. B-lymphocyte calcium influx. Immunol. Rev. 231, 265-277 (2009).

30. Grynkiewicz, G., Poenie, M. \& Tsien, R. Y. A new generation of $\mathrm{Ca}^{2+}$ indicators with greatly improved fluorescence properties. J. Biol. Chem. 260, 3440-3450 (1985).

31. Neher, E. The use of fura-2 for estimating Ca buffers and Ca fluxes. Neuropharmacology 34, 1423-1442 (1995).

32. Malgaroli, A., Milani, D., Meldolesi, J. \& Pozzan, T. Fura-2 measurement of cytosolic free $\mathrm{Ca}^{2+}$ in monolayers and suspensions of various types of animal cells. J. Cell Biol. 105, 2145-2155 (1987). 
33. Hirst, R. A., Harrison, C., Hirota, K. \& Lambert, D. G. Calcium Signaling Protocols 2nd edn, Vol. 312 (ed. Lambert, D.G.) Ch. 2, 37-45 (Humana Press, 2006).

34. Parekh, A. B. \& Putney, J. W. Store-operated calcium channels. Physiol. Rev. 85, 757-810 (2005).

35. Kaupp, U. B. \& Seifert, R. Cyclic nucleotide-gated ion channels. Physiol. Rev. 82, 769-824 (2002).

36. Samways, D., Li, Z. \& Egan, T. Principles and properties of ion flow in P2X receptors. Front. Cell. Neurosci. 8, 1-18 (2014).

37. Helmchen, F., Imoto, K. \& Sakmann, B. $\mathrm{Ca}^{2+}$ buffering and action potential-evoked $\mathrm{Ca}^{2+}$ signaling in dendrites of pyramidal neurons. Biophys. J. 70, 1069-1081 (1996).

38. Noguchi, J., Matsuzaki, M., Ellis-Davies, G. C. \& Kasai, H. Spine-neck geometry determines NMDA receptor-dependent $\mathrm{Ca}^{2+}$ signaling in dendrites. Neuron 46, 609-622 (2005).

39. Grienberger, C. \& Konnerth, A. Imaging calcium in neurons. Neuron 73, 862-885 (2012).

40. Hombach, J., Tsubata, T., Leclercq, L., Stappert, H. \& Reth, M. Molecular components of the B-cell antigen receptor complex of the IgM class. Nature 343, 760-762 (1990).

41. Yokoyama, K. et al. BANK regulates BCR-induced calcium mobilization by promoting tyrosine phosphorylation of $\mathrm{IP}_{3}$ receptor. EMBO J. 21, 83-92 (2002).

42. Prakriya, M. et al. Orail is an essential pore subunit of the CRAC channel. Nature 443, 230-233 (2006).

43. Feske, S. \& Prakriya, M. Conformational dynamics of STIM1 activation. Nat. Struct. Mol. Biol. 20, 918-919 (2013).

44. Oh-hora, M. \& Rao, A. Calcium signaling in lymphocytes. Curr. Opin. Immunol. 20, 250-258 (2008).

45. Feske, S. Calcium signalling in lymphocyte activation and disease. Nat. Rev. Immunol. 7, 690-702 (2007).

46. Rhee, S. G. \& Bae, Y. S. Regulation of phosphoinositide-specific phospholipase C isozymes. J. Biol. Chem. 272, 15045-15048 (1997).

47. Westerman, R. B., He, Y., Keen, J. E., Littledike, E. T. \& Kwang, J. Production and characterization of monoclonal antibodies specific for the lipopolysaccharide of Escherichia coli O157. J. Clin. Microbiol. 35, 679-684 (1997).

48. Lüderitz, O., Staub, A. \& Westphal, O. Immunochemistry of O and R antigens of Salmonella and related Enterobacteriaceae. Bacteriol. Rev. 30, 192-255 (1966).

49. Walshe, C. A. et al. Induction of cytosolic calcium flux by CD20 is dependent upon B Cell antigen receptor signaling. J. Biol. Chem. 283, 16971-16984 (2008).

50. Aliprantis, A. O. et al. Cell activation and apoptosis by bacterial lipoproteins through toll-like receptor-2. Science 285, 736-739 (1999).

51. Fleire, S. et al. B cell ligand discrimination through a spreading and contraction response. Science 312, 738-741 (2006).

52. Oh, B.-K., Kim, Y.-K., Bae, Y., Lee, W. \& Choi, J.-W. Detection of Escherichia coli O157: H7 using immunosensor based on surface plasmon resonance. J. Microbiol. Biotechnol. 12, 780-786 (2002).

53. Wang, N., He, M. \& Shi, H.-C. Novel indirect enzyme-linked immunosorbent assay (ELISA) method to detect Total E. coli in water environment. Anal. Chim. Acta 590, 224-231 (2007).

54. Geng, T., Uknalis, J., Tu, S.-I. \& Bhunia, A. K. Fiber-optic biosensor employing Alexa-Fluor conjugated antibody for detection of Escherichia coli O157: H7 from ground beef in four hours. Sensors 6, 796-807 (2006).

55. Su, X.-L. \& Li, Y. A self-assembled monolayer-based piezoelectric immunosensor for rapid detection of Escherichia coli O157: H7. Biosens. Bioelectron. 19, 563-574 (2004).

56. Setterington, E. B. \& Alocilja, E. C. Rapid electrochemical detection of polyaniline-labeled Escherichia coli O157: H7. Biosens. Bioelectron. 26, 2208-2214 (2011).

57. Huang, C.-J., Dostalek, J., Sessitsch, A. \& Knoll, W. Long-range surface plasmon-enhanced fluorescence spectroscopy biosensor for ultrasensitive detection of E. coli O157: H7. Anal. Chem. 83, 674-677 (2011).

58. Luo, Y. et al. Novel biosensor based on electrospun nanofiber and magnetic nanoparticles for the detection of E. coli O157: H7. IEEE Trans. Nanotechnol. 11, 676-681 (2012).

\section{Acknowledgements}

We are grateful to Robert L. Dienglewicz for cell culture training and Lisa Cooney Kelso for SEM sample preparation and imaging. This research was financially supported in part by Arkansas Biosciences Institute (ABI) and China Ministry of Science and Technology (Project No. 2013BAD19B02).

\section{Author Contributions}

L. W. and R. W. conceived of the method. R. W. and Y. L. supervised the project. B.-W.K., S. J., K. Y. and W.F. co-supervised the project and provided guidance and assistance in cell culture and the manuscript writing. L.W. performed the experiments and wrote the main manuscript with the input from all other authors.

\section{Additional Information}

Supplementary information accompanies this paper at http://www.nature.com/srep

Competing financial interests: The authors declare no competing financial interests.

How to cite this article: Wang, L. et al. B cells Using Calcium Signaling for Specific and Rapid Detection of Escherichia coli O157:H7. Sci. Rep. 5, 10598; doi: 10.1038/srep10598 (2015).

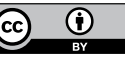

This work is licensed under a Creative Commons Attribution 4.0 International License. The images or other third party material in this article are included in the article's Creative Commons license, unless indicated otherwise in the credit line; if the material is not included under the Creative Commons license, users will need to obtain permission from the license holder to reproduce the material. To view a copy of this license, visit http://creativecommons.org/licenses/by/4.0/ 